\title{
Miniestaquia de mamoeiro hermafrodita ‘Golden’ com indutor auxínico, em sistema semi-hidropônico
}

\author{
Mini-cutting of hermaphrodite papaya 'Golden' with auxin inductor in semi-hydroponic \\ system
}

\author{
Omar Schmildt ${ }^{1 *}$, Edilson Romais Schmildt ${ }^{1}$, Rodrigo Sobreira Alexandre², Marcio José Vieira de \\ Oliveira $^{3}$, Geraldo Antônio Ferreguetti ${ }^{4}$, Adriel Lima Nascimento ${ }^{1}$ e Karina Tiemi Hassuda dos Santos ${ }^{1}$ \\ ${ }^{1}$ Universidade Federal do Espírito Santo, São Mateus, ES, Brasil. Autor para correspondência: omarschmildt@gmail.com. \\ 2Universidade Federal do Espírito Santo, Jerônimo Monteiro, ES, Brasil. \\ ${ }^{3}$ Instituto Federal do Espírito Santo, Alegre, ES, Brasil. \\ ${ }^{4}$ Caliman Agrícola S/A, Linhares, ES, Brasil.
}

Submissão:17/07/2018 / Aceite: 01/07/2019

\begin{abstract}
RESUMO
O mamoeiro tradicionalmente é propagado por sementes. A propagação assexuada é uma alternativa para a produção de plantas hermafroditas com o padrão de frutos exigidos pelo mercado consumidor. Sendo assim, objetivou-se estudar a propagação vegetativa em mamoeiro hermafrodita 'Golden', testando o ácido indol-3-butírico (AIB) no enraizamento de miniestacas, em sistema semi-hidropônico. $O$ delineamento experimental utilizado foi o inteiramente casualizado. Os tratamentos consistiram de cinco concentrações de $\operatorname{AIB}\left(0,3,6,9\right.$ e $\left.12 \mathrm{mg} \mathrm{L}^{-1}\right)$, com quatro repetições de seis miniestacas retiradas de plantas hermafroditas em cada parcela. Após 60 dias do cultivo, as miniestacas foram analisadas quanto à porcentagem de enraizamento, porcentagem de sobrevivência, comprimento da maior raiz, e número de folhas. A concentração em torno de $9 \mathrm{mg} \mathrm{L}^{-1}$ de AIB propiciou uma melhor indução ao enraizamento das miniestacas, bem como maior sobrevivência das mudas, formação de folhas e qualidade de suas raízes. Recomenda-se o uso de $9 \mathrm{mg} \mathrm{\textrm {L } ^ { - 1 }}$ de AIB no sistema semi-hidropônico de produção de mudas usando miniestacas de mamoeiro 'Golden' hermafrodita.
\end{abstract}

PALAVRAS-CHAVE: Carica papaya L., ácido indol-3-butírico, miniestacas, propagação assexuada.

\begin{abstract}
Papaya is traditionally propagated by seeds. Asexual propagation is an alternative for the production of hermaphrodite plants, with the fruit pattern required by the consumer market. The objective of this study was to study the vegetative propagation in 'Golden' hermaphrodite papaya, by testing the indole-3-butyric acid (IBA) in the rooting of mini-cuttings in a semi-hydroponic system. The experimental design was completely randomized. The treatments consisted of five concentrations of IBA $\left(0,3,6\right.$, 9 , and $\left.12 \mathrm{mg} \mathrm{L}^{-1}\right)$, with four replicates of six mini-cuttings taken from hermaphrodite plants in each plot. After 60 days of cultivation, the mini-cuttings were analyzed for rooting percentage, survival percentage, length of the largest root, and the number of leaves. The concentration around $9 \mathrm{mg} \mathrm{L}^{-1}$ of IBA provided a better induction to the rooting of mini-cuttings, as well as greater seedling survival, leaf formation, and root quality. The use of $9 \mathrm{mg} \mathrm{L}^{-1}$ of IBA in the semi-hydroponic system of seedling production is recommended using 'Golden' hermaphrodite papaya mini-cuttings.
\end{abstract}

KEYWORDS: Carica papaya L., indol-3-butyric acid, mini-cuttings, asexual propagation.

\section{INTRODUÇÃO}

A forma de propagação do mamoeiro mais utilizada em todo o mundo é por sementes. Destaca-se que no Brasil o plantio é feito em área aberta e em alguns países da Europa, como na Espanha, em ambiente de cultivo protegido (SALINAS et al. 2017).

No Brasil, as cultivares de mamoeiro plantadas comercialmente são de populações ginóicoandromonóicas, em que as plantas são femininas ou hermafroditas. Para os mercados brasileiro, europeu e americano, a preferência é por frutos oriundos de plantas hermafroditas (SCHMILDT et al. 2015), ao qual 
possuem menor tamanho devido a menor cavidade interna. Portanto, a obtenção de frutos de mamão originados de flores hermafroditas, para produção de frutos pequenos e de forma ovalada, é importante porque atende a necessidade dos consumidores e reduz os custos de transporte, embalagem e armazenamento (FAGUNDES \& YAMANISHI 2001).

Pelo fato da propagação do mamoeiro ser sexuada e, não se conhecer, visualmente, o tipo floral da planta antes do florescimento, a solução é o preparo e plantio de mais de uma muda por cova (ALLAN 2013, SCHMILDT et al. 2015). Para variedades como o 'Golden', tem-se recomendado plantar três mudas por cova, o que proporciona, após a adequada sexagem (desbaste das mudas femininas), cerca de $96 \%$ de plantas hermafroditas na lavoura, implicando em aumento dos custos de produção (SCHMILDT et al. 2015), além de afetar o desenvolvimento das plantas hermafroditas em razão da competição por água, luz e nutrientes minerais (FITCH et al. 2005, FERREIRA et al. 2011).

Não existe nenhum caráter morfológico visual que seja totalmente eficiente para distinguir o sexo do mamoeiro em plantas juvenis (CHUTTEANG et al. 2007). Embora algumas pesquisas apontem a identificação precoce do sexo por meio de marcadores moleculares (DEPUTY et al. 2002, OLIVEIRA et al. 2007), a análise ainda não é viável economicamente, para as condições de plantio em áreas abertas. Dessa forma, a propagação vegetativa, a partir da estaquia, se torna alternativa à propagação seminífera.

A técnica da estaquia utiliza órgãos vegetativos das plantas, objetivando a formação de raízes adventícias em resposta à indução auxínica, e inclui processos de desdiferenciação, rediferenciação, alongamento e divisão celular. Esta técnica apresenta como vantagens, o porte reduzido, a uniformidade e precocidade de produção, a manutenção das características genéticas das plantas matrizes (HARTMANN et al. 2011), e em mamoeiro também a obtenção de mudas 100\% hermafroditas (ALLAN 1990, SCHMILDT et al. 2016, OLIVEIRA et al. 2018). O mamoeiro possui baixa ou nenhuma capacidade de enraizamento nas estacas, devendo assim ser tratadas com auxinas (SCHMILDT et al. 2015). Normalmente, se utiliza a aplicação de auxina visando reduzir o balanço citocinina/auxina, para promover uma maior porcentagem, velocidade, qualidade e uniformidade de enraizamento (HARTMANN et al. 2011).

O ácido indol-3-butírico (AIB) é a auxina mais utilizada no enraizamento de estacas, por se tratar de substância fotoestável, de ação localizada, menos sensível à degradação biológica, e devido à maior aderência à estaca (FACHINELLO et al. 2005). Segundo ALLAN (1990), as estacas de mamoeiro podem ser enraizadas por meio da utilização de AIB, sob nebulização intermitente e temperatura mínima em torno de $30 \stackrel{\circ}{ } \mathrm{C}$ no substrato areia, com leito aquecido. Este sistema utilizando AIB, entretanto, sem leito aquecido, mostrou-se eficiente no enraizamento de macroestacas em substrato areia (SCHMILDT et al. 2016) e, em miniestacas em sistema semi-hidropônico, proposto por OLIVEIRA et al. (2018).

A miniestaquia de mamoeiro em sistema semi-hidropônico conforme proposto por OLIVEIRA et al. (2018) quando comparada com a macroestaquia citado por SCHMILDT et al. (2016), tende a ser mais econômico, pois possibilita a utilização de concentrações menores de AIB na indução ao enraizamento das estacas e o cultivo das plantas matrizes em casa de vegetação, também atenua a disseminação de doenças viróticas na propagação e otimiza o espaço em viveiro.

Há diferenças marcantes na resposta rizogênica de macroestacas de diferentes genótipos de mamoeiro pela indução com AIB, sendo que, SCHMILDT et al. (2016) demonstraram que o genótipo 'Golden' é pouco responsivo. Sendo assim, objetivou-se analisar caracteres morfológicos de miniestacas de mamoeiro hermafrodita 'Golden', em resposta a aplicação de AIB na indução do enraizamento, em sistema semi-hidropônico.

\section{MATERIAL E MÉTODOS}

O experimento foi realizado em duas etapas, em que a primeira refere-se ao preparo das plantas matrizes, feito no Centro Universitário Norte do Espírito Santo/UFES, em São Mateus, ES, e a segunda, ao enraizamento das miniestacas, conduzido na Fazenda Santa Terezinha, pertencente à empresa Caliman Agrícola S/A, em Linhares, ES.

Na primeira etapa foi feita a indução das brotações laterais (miniestacas) em plantas matrizes de mamoeiro 'Golden', cultivadas em casa de vegetação, em vasos de 12 litros. O substrato utilizado era composto por terra de barranco, areia e esterco bovino bem curtido, na proporção 3:1:1, respectivamente. Foram realizadas mensalmente adubações com 2,5 g de formulado NPK: $13-40-13$ e 3,5 g de nitrato de cálcio por planta, conforme OLIVEIRA et al (2018). Controle fitossanitário foi realizado sempre que necessário, conforme orientações para mamoeiro. As condições ambientais da casa de vegetação foram controladas pelo sistema de nebulização intermitente, que era acionado quando a temperatura atingisse $31^{\circ} \mathrm{C}$, condições estas que mantiveram a temperatura em torno de $28,3 \pm 3 \stackrel{\circ}{\circ} \mathrm{C}$, e umidade relativa do ar 
com $73,8 \pm 7 \%$. Para a indução das brotações foram realizadas podas somente em plantas hermafroditas, após a devida sexagem, com cerca de cinco meses de idade e, nesta ocasião removeu-se inicialmente cerca de 6 a $10 \mathrm{~cm}$ do ápice da planta. Após 30 dias foi feita poda nos brotos que surgiram ao longo do caule das plantas, deixando no mínimo duas gemas, de acordo com o tamanho da brotação. Este procedimento foi repetido a cada 30 dias por três vezes com o objetivo de aumentar o número de brotações.

$\mathrm{Na}$ segunda etapa, as miniestacas foram coletadas após a quarta poda sequencial efetuada nos brotos laterais, em plantas matrizes com aproximadamente 10 meses de idade, em maio de 2014. A coleta das miniestacas foi feita no período da manhã, quando as plantas não se encontravam com deficiência hídrica, sendo estas mantidas em baldes com água até o momento do preparo para o estaqueamento. As miniestacas herbáceas foram coletadas com tamanhos de $7 \pm 0,5 \mathrm{~cm}$ de comprimento, e na sequência preparadas deixando duas folhas por estaca, sendo retirados os limbos foliares das demais folhas basais, mantendo-se $1 \mathrm{~cm}$ de pecíolo e, tratadas com fungicida/bactericida Agrimaicin ${ }^{\circledR} 500$ a $2 \mathrm{~g} \mathrm{~L}^{-1}$, por 20 minutos.

Neste experimento de indução ao enraizamento das miniestacas foram utilizados como tratamentos, o AIB nas concentrações de 0; 3; 6; 9 e $12 \mathrm{mg} \mathrm{L}^{-1}$, com quatro repetições, sendo cada uma delas constituída de seis estacas. O delineamento foi o inteiramente casualizado.

As estacas foram cultivadas em sistema semi-hidropônico, conforme OLIVEIRA et al. (2018). Inicialmente foram preparadas as bandejas de isopor de 32 células $(3,5 \times 3,5 \times 6,0 \mathrm{~cm})$, preenchendo cada célula com substrato inerte, a vermiculita expandida de textura média foi previamente umedecida para facilitar o estaqueamento. Na sequência foi feito o estaqueamento. As bandejas de isopor contendo as miniestacas foram colocadas dentro de bandejas plásticas, foram inseridas em cada uma, dois litros de água, acrescida de solução nutritiva de FURLANI et al. (1999) juntamente com o AIB, conforme os tratamentos mencionados já anteriormente. A água e a solução nutritiva foram trocadas a cada sete dias. Já o AIB permaneceu na água somente na primeira semana.

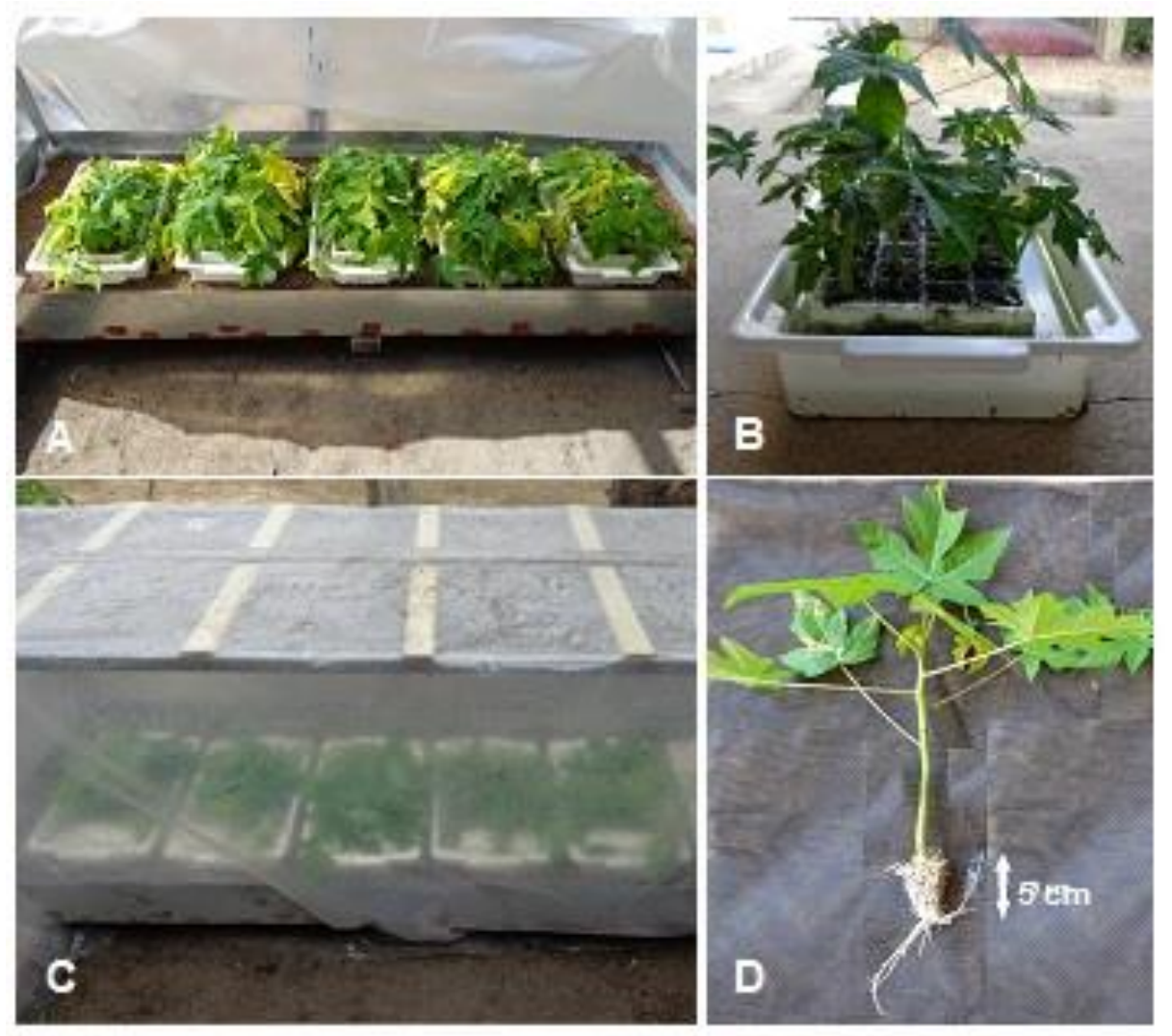

Figura 1. Processo de miniestaquia em estufim, em sistema semi-hidropônico: (A) parte interna = bandejas plásticas (contendo as bandejas de isopor) postas na câmara sobre a vermiculita; (B) miniestacas enraizadas após 60 dias de cultivo; (C) parte externa = câmara úmida coberta com plástico branco, mantida sob sombrite $70 \%$, após 60 dias de cultivo; (D) Detalhe de miniestaca enraizada.

Figure 1. Process of mini-cutting in the semi-hydroponic system: $(A)$ internal part = plastic trays (containing the styrofoam trays) placed in the chamber on the vermiculite; $(B)$ external part $=$ wet chamber covered with white plastic, kept under $70 \%$ sombrite, (C) mini-cuttings rooted after 60 days of cultivation; (D) Rooted mini-stake detail. 
Para a manutenção da umidade adequada no ambiente de cultivo foi utilizada uma câmara úmida (estufim), mantida sob sombrite 70\% (Figuras 1A e C), como empregada por SCHMILDT et al. (1997). Neste ambiente, utilizou-se plástico branco para fechar a câmara. No local aonde foram depositadas as bandejas plásticas, adicionou-se vermiculita para manter o ambiente com a umidade mais elevada, em torno de $80 \pm$ $10 \%$, favorável as miniestacas, para evitar a sua desidratação e morte. A vermiculita da câmara úmida foi molhada semanalmente, na mesma época da troca de água e da solução nutritiva. A temperatura média mínima e máxima registrada no ambiente da câmara úmida durante o período de cultivo das estacas foi de 24 e $30,5^{\circ} \mathrm{C}$, respectivamente. Já a temperatura no substrato oscilou entre 25 e $32{ }^{\circ} \mathrm{C}$.

Durante os 60 dias de experimento, a umidade relativa do ar e a temperatura do substrato e do ar foram monitoradas pelo sensor WatchDog Datalogger, em intervalos de uma uma hora. As figuras 1B e C demonstram as miniestacas no último dia de cultivo neste ambiente, enquanto a figura $D$ enfatiza a miniestaca enraizada.

A análise deste experimento aconteceu em julho, após 60 dias da implantação. Nesta ocasião, analisou-se a porcentagem de enraizamento, porcentagem de plantas sobreviventes, comprimento da maior raiz, e número de folhas.

Nos dados coletados procedeu-se à análise de variância após verificação dos pressupostos da normalidade e homocedasticidade. Posteriormente procedeu-se à análise de regressão, com coeficientes sendo avaliados pelo teste de $\mathrm{F}$ a 5 e $1 \%$ de significância para o erro tipo I. Todas as análises foram realizadas com auxílio do software Genes (CRUZ 2016).

\section{RESULTADOS E DISCUSSÃO}

Os resultados encontrados neste trabalho evidenciaram comportamento quadrático positivo para todas as variáveis estudadas.

A sobrevivência das miniestacas de mamoeiro 'Golden' foi influenciada pelas concentrações de AIB, sendo a mais elevada $(65,84 \%)$ com a indução ao enraizamento a 9,33 $\mathrm{mg} \mathrm{L}^{-1}$ (Figura 2).

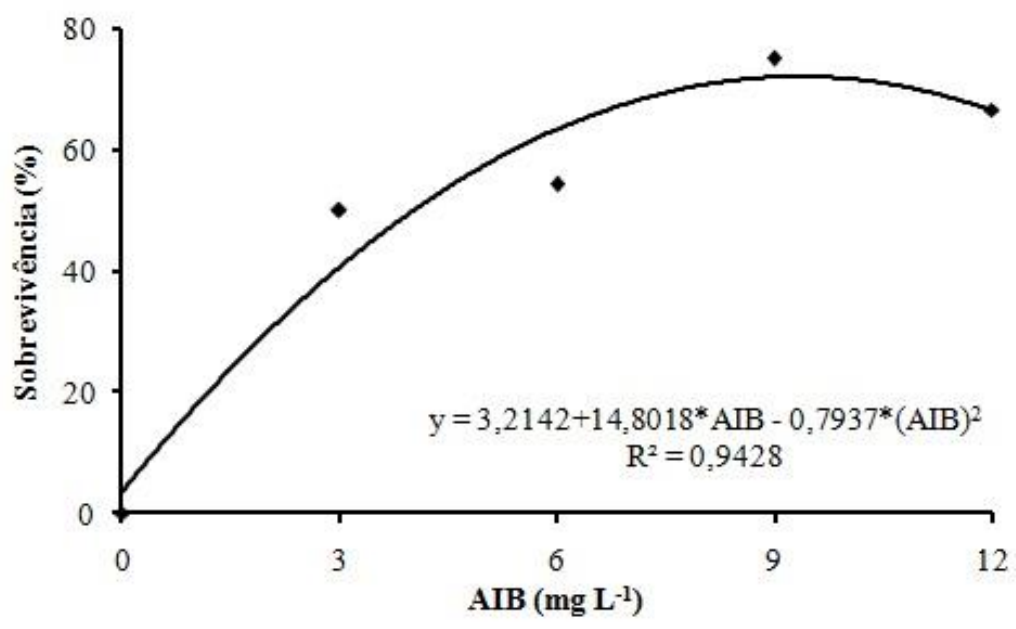

Figura 2. Sobrevivência de miniestacas de mamoeiro 'Golden' submetidas a diferentes concentrações de AIB, em sistema semi-hidropônico. *Significativo a $5 \%$ de probabilidade pelo teste $\mathrm{F}$.

Figure 2. Survival of 'Golden' papaya mini-cuttings submitted to different AlB concentrations in a semihydroponic system. *'Significant at 5\% probability by F-test.

Nos sistemas de propagação por estaquia, a sobrevivência e o enraizamento das estacas estão condicionadas a umidade do ambiente de cultivo, evidenciando que grande parte das perdas em mudas clonais estão relacionadas ao déficit hídrico nas estacas. Os sistemas de propagação com alta umidade relativa minimizam a perda de água pelas estacas, principalmente nas fases iniciais, quando não existem raízes formadas (HARTMANN et al. 2011). Desta forma, neste trabalho com mamoeiro 'Golden' utilizou-se a câmara úmida, proposta por SCHMILDT et al. (1997), ao qual mantêm a umidade relativa do ar próximo de $80 \pm 10 \%$, além de utilização de concentrações menores de AIB, abaixo de $12 \mathrm{mg} \mathrm{L}^{-1}$, para assim promover o aumento da taxa de sobrevivência das mudas. OLIVEIRA et al. (2018) trabalhando com miniestacas de mamoeiro 'Uenf/Caliman 02', em câmara úmida, no sistema semi-hidropônico, também verificaram comportamento quadrático para a variável sobrevivência, ao qual obteve o ponto máximo com $4,99 \mathrm{mg} \mathrm{L}^{-1}$ de AIB, proporcionando $74,93 \%$ de mudas sobreviventes. 
De acordo com os resultados encontrados neste experimento, constatou-se que a não utilização do AIB, não promoveu o enraizamento das miniestacas (Figura 3), e por conseqüência houve a mortalidade das mesmas. Conforme estes resultados, verifica-se baixo nível endógeno de auxinas nos ramos de mamoeiro, reforçando a necessidade da indução com auxina sintética para potencializar o enraizamento das estacas (HARTMANN et al. 2011, SCHMILDT et al. 2015, OLIVEIRA et al. 2018). A ausência de enraizamento devido a não utilização de AIB também foi observado por outros autores que trabalharam com o mamoeiro, tanto em propagação in vitro (SCHMILDT et al. 2009), quanto por estaquia (SCHMILDT et al. 2016, OLIVEIRA et al. 2018).

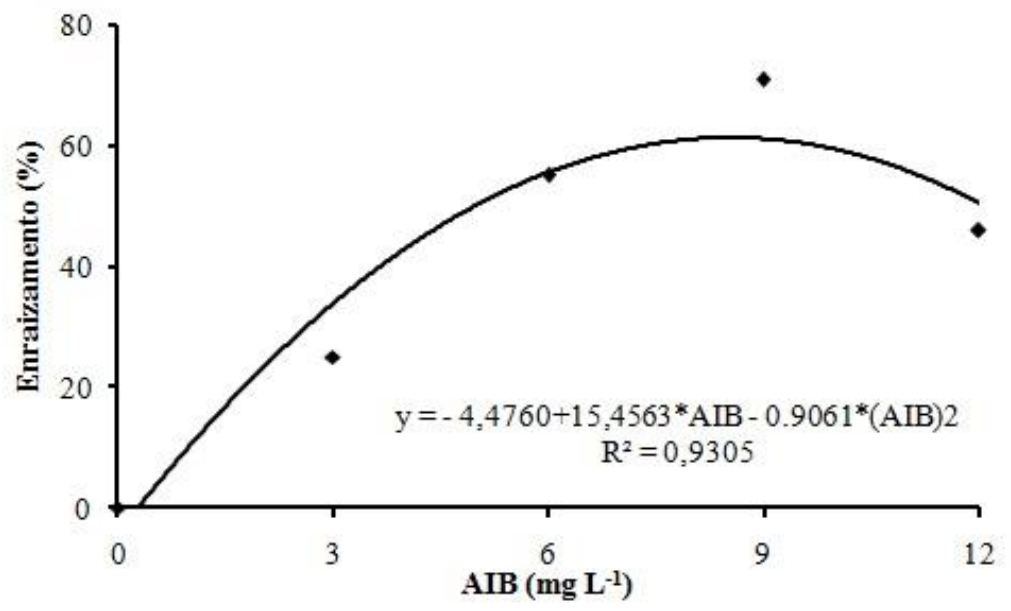

Figura 3. Enraizamento de miniestacas de mamoeiro 'Golden' submetidas a diferentes concentrações de AIB, em sistema semi-hidropônico. *Significativo a $5 \%$ de probabilidade pelo teste $\mathrm{F}$.

Figure 3. Rooting of 'Golden' papaya mini-cuttings submitted to different concentrations of IBA in a semihydroponic system. *Significant at $5 \%$ probability by F-test.

A resposta rizogênica apresentou comportamento quadrático, com ponto máximo de enraizamento de $8,53 \mathrm{mg} \mathrm{L}^{-1}$ de AIB, com $61,44 \%$ de enraizamento (Figura 3). Resultados similares foram encontrados por OLIVEIRA et al. (2018) em miniestacas do híbrido 'UENF Caliman 02', com 61,66\% de enraizamento em $6,17 \mathrm{mg} \mathrm{L}^{-1}$ de AIB, utilizando vermiculita como substrato. $O$ processo de semi-hidroponia por meio de miniestacas de mamoeiro proposto por OLIVEIRA et al. (2018) apresenta como vantagem o enraizamento na faixa dos $70 \%$, que segundo HARTMANN et al. (2011) é o percentual mínimo para que o processo de estaquia seja viável comercialmente.

O sucesso no processo de propagação por estaquia é dependente de muitos fatores, tanto internos, quantos externos. Dentre estes, citam-se, o potencial genético de enraizamento, as condições nutricional e fitossanitária da planta matriz, a época do ano de coleta das estacas, o balanço hormonal, a temperatura, luz, umidade e maturação/juvenilidade dos propágulos (FACHINELLO et al. 2005, HARTMANN et al. 2011). Os resultados encontrados abaixo do ideal neste experimento (61,44\% de enraizamento) (Figura 3) pode ser explicado pela época de sua realização, ou seja, em período de temperaturas mais amenas. Segundo ALLAN (1990), as estacas de mamoeiro para enraizarem precisam de temperatura mínima em torno de $30{ }^{\circ} \mathrm{C}$ no substrato, em leito aquecido. Durante o tempo de realização do experimento com mamoeiro 'Golden', a temperatura no substrato oscilou entre 25 e $32{ }^{\circ} \mathrm{C}$, sendo que na primeira semana, que é a época importante de indução ao enraizamento das miniestacas, a temperatura ficou abaixo da indicada por ALLAN (1990). O enraizamento pode também estar relacionado à lignificação das estacas (CARVALHO et al. 2015). De acordo com FACHINELLO et al. (2005), as estacas coletadas no inverno são mais lignificadas e possuem menor capacidade de enraizamento, e se coletadas em um período de crescimento vegetativo intenso (primavera/verão) tendem a enraizar mais. Essa queda na capacidade de enraizamento pode deverse a variações no conteúdo de co-fatores ou à formação e acúmulo de inibidores de enraizamento (NACHTIGAL et al. 1999), como os compostos fenólicos, triazóis, carboidratos, boro, entre outros (HARTMANN et al. 2011).

Outra variável tão importante quanto a porcentagem de enraizamento das miniestacas é a qualidade das raízes formadas. Neste experimento foi avaliado o comprimento da maior raiz, onde também nota-se que houve o mesmo comportamento quadrático (Figura 4) verificado para o enraizamento. O ponto máximo de comprimento da maior raiz $(9,11 \mathrm{~cm})$ foi obtido com a utilização de $8,6 \mathrm{mg} \mathrm{L}^{-1}$ de AIB. Os resultados 
encontrados estão de acordo com HARTMANN et al (2011), ao qual enfatizam que o aumento da concentração de auxinas aplicadas nas estacas, estimula a formação de raízes até um ponto máximo, a partir do qual, o acréscimo se torna inibitório. Ainda, ROSOLEM et al. (1999) citam que a capacidade de absorção de nutrientes está relacionada com o comprimento radicular. Portanto, na miniestaquia, em sistema semi-hidropônico, o maior comprimento da raiz torna-se benéfico a absorção de nutrientes da solução nutritiva para formação da parte aérea.

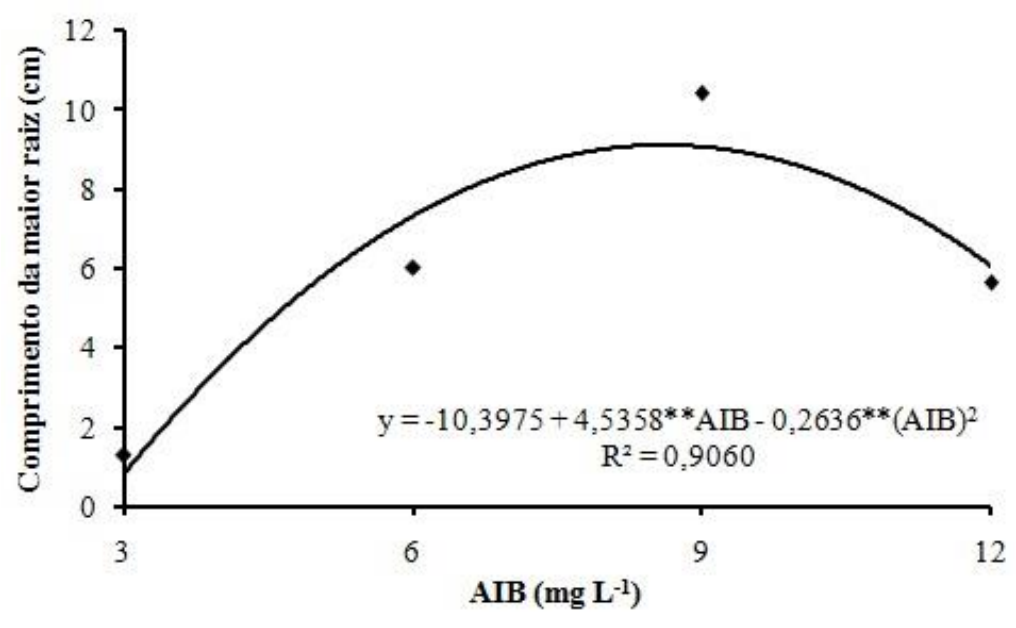

Figura 4. Comprimento da maior raiz de miniestacas de mamoeiro 'Golden' submetidas a diferentes concentrações de AIB, em sistema semi-hidropônico. ${ }^{* *}$ Significativo a $1 \%$ de probabilidade pelo teste F.

Figure 4. Length of the largest root of 'Golden' papaya mini-cuttings submitted to different concentrations of $I B A$, in a semi-hydroponic system. ${ }^{*}$ Significant at $1 \%$ probability by F-test.

Para o cálculo do número de folhas, procedeu-se a contagem por estacas, somente naquelas sobreviventes. A maior quantidade de folhas $(6,12)$ foi observada com AIB na concentração de $10,81 \mathrm{mg} \mathrm{L}^{-1}$ (Figura 5). Os resultados encontrados evidenciaram que a maior quantidade de folhas nas estacas proporcionou maior taxa de enraizamento. Estes resultados estão em conformidade com os encontrados por SCHMILDT et al. (2016) em experimentos de enraizamento com mamoeiro 'Golden' e 'Uenf/Caliman 01'. De acordo com os autores, a taxa de fotossíntese líquida encontrada nos experimentos foi influenciada pela quantidade de folhas nas estacas. Assim sendo, a taxa fotossintética foi mais elevada nas estacas com número maior de folhas, o que reflete na resposta rizogênica, pois favorece a relação $\mathrm{C} / \mathrm{N}$ para rizogênese. O efeito das folhas é explicado pela continuidade da fotossíntese na estaca, fornecendo carboidratos, fitorreguladores e outras substâncias necessárias para o estímulo e crescimento das raízes adventícias (HARTMANN et al. 2011).

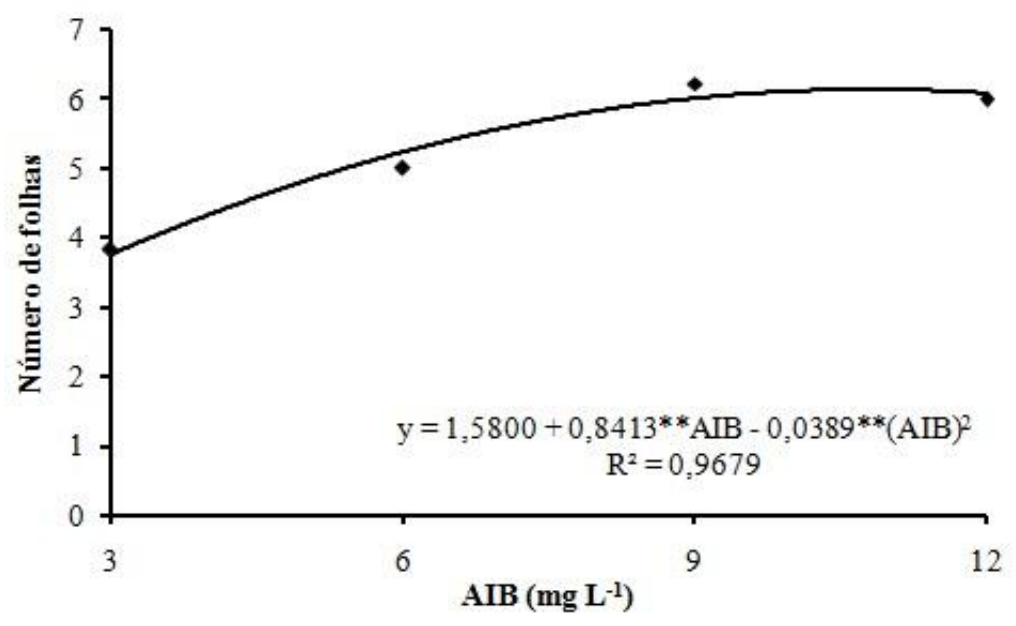

Figura 5. Número de folhas em miniestacas de mamoeiro 'Golden' submetidas a diferentes concentrações de AIB, em sistema semi-hidropônico. ${ }^{*}$ Significativo a $1 \%$ de probabilidade pelo teste $\mathrm{F}$.

Figure 5. The number of leaves in 'Golden' papaya mini-cuttings submitted to different concentrations of IBA, in a semi-hydroponic system. **Significant at $1 \%$ probability by F-test. 
Em mudas de mamoeiro produzidas via sementes, em tubetes, na época de transplantio, que ocorre cerca de 20 a 30 dias da germinação (EMBRAPA 2009) verifica-se uma boa qualidade quando estas apresentam aproximadamente quatro folhas, como encontrados por PAIXÃO et al. (2012), em 'Golden THB' e, por CELANTI et al. (2016), em 'Golden Peciolo curto'. Comparando-se as mudas produzidas via sementes com as produzidas neste experimento de miniestaquia, nota-se que 6,12 folhas obtidos utilizando $9 \mathrm{mg} \mathrm{L}^{-1}$ de AIB é um bom idicativo de vigor, sendo estas propicias ao transplantio.

OLIVEIRA et al. (2018) indicam para o processo de produção de mudas a partir de miniestacas de mamoeiro 'UENF/Caliman 02', a concentração de $5 \mathrm{mg} \mathrm{L}^{-1}$ de AIB, enquanto que neste trabalho com mamoeiro 'Golden', indica-se $9 \mathrm{mg} \mathrm{L}^{-1}$ de AIB. Sendo portanto, concentrações bem inferiores ao enraizamento de macroestacas de mamoeiro, que requer de 1000 à $4000 \mathrm{mg} \mathrm{L}^{-1}$ de $\mathrm{AlB}$, como nos trabalhos de ALLAN (1990), ALLAN (2013) e SCHMILDT et al. (2016). Portanto, o resultado de $61,44 \%$ de enraizamento alcançado neste trabalho de miniestaquia com mamoeiro 'Golden' em sistema semihidropônico é considerado um avanço na produção de mudas para esta cultivar, quando comparado aos resultados alcançados por SCHMILDT et al. (2016) em macroestacas de mamoeiro 'Golden', que obtiveram $17 \%$ de enraizamento, utilizando $3000 \mathrm{mg} \mathrm{L}^{-1}$ de AIB. No avanço citado anteriormente com a utilização do sistema semi-hidropônico, destaca-se a economia do processo na produção de mudas, bem como a obtenção de mudas sadias a partir de matrizes cultivadas em casa de vegetação, quando comparado a macroestaquia.

\section{CONCLUSÃO}

Indica-se a concentração de $9 \mathrm{mg} \mathrm{L}^{-1}$ de AIB para a indução do enraizamento de miniestacas de mamoeiros 'Golden' hermafroditas, em sistema semi-hidropônico.

\section{AGRADECIMENTOS}

A Coordenação de Aperfeiçoamento de Pessoal de Nível Superior (CAPES), pelo suporte financeiro e bolsa fornecida ao primeiro autor e, a Universidade Federal do Espírito Santo (UFES) e Caliman Agrícola S/A pela logística na realização do experimento.

\section{REFERÊNCIAS}

ALLAN P. 2013. Selection and vegetative propagation of superior bisexual papayas. South African Fruit Journal 12: 38 39.

ALLAN P. 1990. Vegetative propagation and production of 'Honey Gold' papayas. Acta Horticulturae 269: $105-111$.

CARVALHO JSB et al. 2015. Influência de diferentes tipos de estacas e substratos na propagação vegetativa de Hyptis pectinata. Revista de Ciências Agroveterinárias 14: 89-91.

CELANTI HF et al. 2016. Optimal plot size in the evaluation of papaya scions: proposal and comparison of methods. Revista Ceres 63: 469-476.

CHUTTEANG C et al. 2007. Leaf photosynthetic potential of female and hermaphrodite papaya (Carica papaya cv. Khaeg Nuan). Acta Horticulturae 740: 197-202.

CRUZ CD. 2016. Genes Software - extended and integrated with the R, Matlab and Selegen. Acta Scientiarum Agronomy 38: 547-552.

DEPUTY JC et al. 2002. Molecular markers for sex determination in papaya (Carica papaya L.). Theoretical and Applied Genetics 106: 107-111.

EMBRAPA. 2009. Empresa Brasileira de Pesquisa Agropecuária. A cultura do mamão. 3.ed. Brasília: Embrapa. 119p. (Coleção Plantar 65).

FACHINELLO JC et al. 2005. Propagação vegetativa por estaquia. In: FACHINELLO JC et al (Eds.). Propagação de plantas frutíferas de clima temperado. Brasília: Embrapa. p.69-109.

FAGUNDES GR \& YAMANISHI OK. 2001. Características físicas e químicas de frutos de mamoeiro do grupo 'solo' comercializados em 4 estabelecimentos de Brasília-DF. Revista Brasileira de Fruticultura 23: 541-545.

FERREIRA JP et al. 2011. Enraizamento in vitro de clones de mamoeiro 'Tainung 01'. Revista Ciência Agronômica 42 : 563-566.

FITCH MMM et al. 2005. Clonally propagated and seed-derived papaya orchards: 1 plant production and field growth. HortScience 40: 1283-1290.

FURLANI PR et al. 1999. Cultivo hidropônico de plantas. Campinas: Instituto Agronômico. 52p. (Boletim Técnico 180).

HARTMANN HT et al. 2011. Plant propagation: principles and practices. 8.ed. New Jersey: Prentice Hall. 915p.

NACHTIGAL JC et al. 1999. Propagação vegetativa do umezeiro (Prunus mume) por meio de estacas herbáceas.

Revista Brasileira de Fruticultura 21: 226-228.

OLIVEIRA EJ et al. 2007. Marcadores moleculares na predição do sexo em plantas de mamoeiro. Pesquisa Agropecuária Brasileira 42: 1747-1754.

OLIVEIRA MJV et al. 2018. IBA levels and substrates in the rooting of UENF/CALIMAN 02 hybrid papaya minicuttings in 
a semi-hydroponic system. Revista Brasileira de Fruticultura 40: e-153.

PAIXÃO MVS et al. 2012. Frações orgânicas e mineral na produção de mudas de mamoeiro. Revista Brasileira de Fruticultura 34: 1105-1112.

ROSOLEM CA et al. 1999. The significance of root growth on cotton nutrition in an acidic low-P soil. Plant and Soil 212: 185-190.

SALINAS I et al. 2017. Comparación de los sistemas productivos de la papaya en España y Brasil. Vida Rural 3: 18-24.

SCHMILDT ER et al. 2009. Resposta rizogênica in vitro de ápices caulinares de mamoeiro 'Tainung 01' em diferentes tempos de permanência em meios de indução e regeneração. Acta Scientiarum. Agronomy 31: 695-700.

SCHMILDT ER et al. 2015. Propagação assexuada de mamoeiro. In: ZUCOLOTO M et al. (Eds). Fruticultura Tropical: Diversificação e Consolidação. Alegre: CAUFES. p.157-175.

SCHMILDT ER et al. 1997. Enraizamento de ramos de mamoeiro (Carica papaya L.) obtidos por cultivo in vitro de ápices caulinares. Revista Ceres 44: 339-345.

SCHMILDT O et al. 2016. Effects of indol butyric acid concentration on propagation from cuttings of papaya cultivars 'Golden' and 'Uenf/Caliman 01'. Fruits 71: 27-33. 